\title{
Modification of Poly(ether ether ketone) Polymer for Fuel Cell Application
}

\author{
Devesh Shukla, ${ }^{1}$ Yuvraj Singh Negi, ${ }^{1}$ and Vijai Kumar ${ }^{2}$ \\ ${ }^{1}$ Department of Polymer and Process Engineering, Indian Institute of Technology, Roorkee 247001, India \\ ${ }^{2}$ Central Institute of Plastic Engineering and Technology, Lucknow 226008, India \\ Correspondence should be addressed to Yuvraj Singh Negi; yuvrajnegi@gmail.com
}

Received 10 April 2013; Accepted 1 October 2013

Academic Editor: Luqman Chuah Abdullah

Copyright (c) 2013 Devesh Shukla et al. This is an open access article distributed under the Creative Commons Attribution License, which permits unrestricted use, distribution, and reproduction in any medium, provided the original work is properly cited.

\begin{abstract}
Polyelectrolyte membrane (PEM) is an important part of PEM fuel cell. Nafion is a commercially known membrane which gives the satisfactory result in PEM fuel cell operating at low temperature. Present research paper includes functionalization of Poly(ether ether ketone) (PEEK) polymer with phosphonic acid group. The functionalization was done with the help of nickel-based catalyst. Further, the polymer was characterized by the FTIR, EDAX, DSC, TGA, and ${ }^{1} \mathrm{H}$ NMR, and it was found that PEEK polymer was functionalized with phosphonic acid group with good thermal stability in comparison to virgin PEEK. Finally, the thin films of functionalized polymer were prepared by solution casting method, and proton conductivity of film samples was measured by impedance spectra whose value was found satisfactory with good thermal stability in comparison to commercially available Nafion membrane.
\end{abstract}

\section{Introduction}

PEEK is a semicrystalline aromatic polymer having high melting temperature $\left(335^{\circ} \mathrm{C}\right)$ and very low or no solubility in ordinary solvents at room temperature. Sulfuric acid is the common solvent which dissolves and also sulfonates PEEK at room temperature. Dilute solutions at high temperatures can also be obtained in hydrofluoric acid, trifluoromethanesulfonic acid, dichlorotetrafluoroacetone monohydrate, phenol 1,2,4-trichlorobenzene, and benzophenone [1]. Therefore, modification of PEEK is typical to some extent but desired for many applications such as polymer electrolyte membrane fuel cell (PEMFC) where acid functionalized polymer is required. In case of PEEK, functionalization in polymer stage is mostly reported on sulfonation and nitration [2]. Phosphonation of polymer is one of the methods to modify their properties such as proton conductivity, mechanical and thermal stability, and in polymer stage it was reported by various groups. Alexandratos et al. [3] reported the phosphonation of polystyrene using $\mathrm{PCl}_{3}$ which gave the cross-linked polymer. However, Jakoby et al. [4] reported that the highly substituted phosphonic acid derivative of polyphenylsulfone (PPS) was achieved via the Pd-dibenzylideneacetone ( $\mathrm{dba}$ ) complexed catalyst in solvent diphenyl ether. Increase of reaction temperature from $90^{\circ} \mathrm{C}$ to $120^{\circ} \mathrm{C}$ also enhanced the substitution level. Bock et al. [5] reported phosphonation of the polysulfones (PSU) using nickel chloride and silylated phosphonates. The route was found less expensive and gave the halogen free product in comparison to palladium-based catalytic route. Lafitte and Jannasch [6] reported a phosphonation of polysulfones via the lithiation of polymer and subsequent conversion of lithiated sites in to phosphonate unit. The substitution level in lithiation route was found very low.

The above efforts have been done on polysulfones polymer. However, in present paper we have done phosphonation of PEEK polymer by utilizing the well-known MichaelisArbuzov Reaction route [7]. Various characterization techniques such as FTIR, EDAX, and NMR supported the phosphonation PEEK with high thermal stability in comparison to PEEK polymer. The proton conductivity of P-PEEK film was also compared with Nafion at $>100^{\circ} \mathrm{C}$ which showed slightly lower value than Nafion.

\section{Experimental}

2.1. Materials and Methods. The commercial available GatoneTM PEEK polymer was obtained by Gharda Chemical India; 
TABLE 1: Calculated wt $\%$ of elements in Br-PEEK.

\begin{tabular}{lccc}
\hline Element & PEEK & Br-PEEK & $(\mathrm{Br})_{2}$-PEEK \\
\hline $\mathrm{C}$ & 82.61 & 64.06 & 52.32 \\
$\mathrm{O}$ & 17.39 & 13.48 & 11.01 \\
$\mathrm{Br}$ & 0 & 22.45 & 36.66 \\
\hline
\end{tabular}

TABLE 2: Measured wt $\%$ of elements in Br-PEEK.

\begin{tabular}{lccccc}
\hline \multirow{2}{*}{ Element } & & \multicolumn{5}{c}{$\mathrm{wt} \%$} \\
& PEEK & $3 \mathrm{~h}$ & $6 \mathrm{~h}$ & $9 \mathrm{~h}$ & $24 \mathrm{~h}$ \\
\hline $\mathrm{C}$ & 86.63 & 66.71 & 59.48 & 54.33 & 48.27 \\
$\mathrm{O}$ & 13.37 & 12.86 & 11.73 & 10.8 & 8.31 \\
$\mathrm{Br}$ & - & 20.43 & 28.79 & 34.87 & 43.42 \\
\hline
\end{tabular}

however, reagent grade $\mathrm{NiCl}_{2}$ and Triethyl phosphate were purchased from Sigma-Aldrich, India. Liquid bromine was obtained from MERK India Ltd, India. Dimethyl acetamide (DMAC) and N-Methyl-2-pyrrolidone (NMP) were purchased from HiMedia Laboratories, India.

2.2. Synthesis of Brominated PEEK (Br-PEEK). All glass wares and PEEK polymer were completely dried at $110^{\circ} \mathrm{C}$ overnight before use. The reaction assembly was established in fumehood with help of three necks round bottom flask, mechanical stirrer and gas washing bottle attached with nitrogen supply. $15 \mathrm{~g}(0.052 \mathrm{~mol}$.) of completely dried PEEK powder were charged in flask containing a mixture of $4 \mathrm{~mL}(0.156 \mathrm{~mol}$.) liquid bromine and $150 \mathrm{~mL}$ of concentrated $\mathrm{H}_{2} \mathrm{SO}_{4}$. The reaction mixture was stirred at ambient temperature for $24 \mathrm{~h}$. The brominated samples were collected at $3 \mathrm{~h}, 6 \mathrm{~h}, 9 \mathrm{~h}$, and $24 \mathrm{~h}$ time intervals and attributed as $3 \mathrm{~h}, 6 \mathrm{~h}, 9 \mathrm{~h}$, and $24 \mathrm{~h}$ respectively. The polymer was precipitated into ice cold distilled water and further washed with several portions of distilled water, methanol, respectively. To ensure bromine free sample, the polymer was extracted with methanol for $8 \mathrm{~h}$. A white modified polymer was obtained which was finally dried in vacuum oven. To obtain the powder sample, the polymer was grinded in Retsch MM 400 Mixture Mill. Modified polymer was readily soluble in a common organic solvent such as Dimethyl sulfoxide (DMSO), DMAC, Chloroform, and Tetrahydrofuran (THF).

\subsection{Aryl Phosphonation of Monobrominated PEEK (Br-PEEK)}

(a) Tetrakis(triethylphosphite)nickel(0). Tetrakis(triethylphosphite)nickel(0) compound was synthesized by the previ ously reported method [7]. About $4.0 \mathrm{~g}$ of Tetrakis(triethylphosphite)nickel(0) (melting point $106-109^{\circ} \mathrm{C}$ ) was obtained.

(b) Phosphonation of Br-PEEK. Solution of $12 \mathrm{~g}(0.033 \mathrm{~mol})$ $3 \mathrm{~h}$ Br-PEEK in $150 \mathrm{~mL}$ DMAC was prepared in a reactor equipped with oil bath, gas inlet and outlet, thermometer, condenser, and dropping funnel. A cold trap was attached to the head of the reflux condenser. The temperature of solution was raised up to $100^{\circ} \mathrm{C}$. Subsequently, a solution of freshly prepared tetrakis(triethylphosphite)nickel(0) in DMAC was

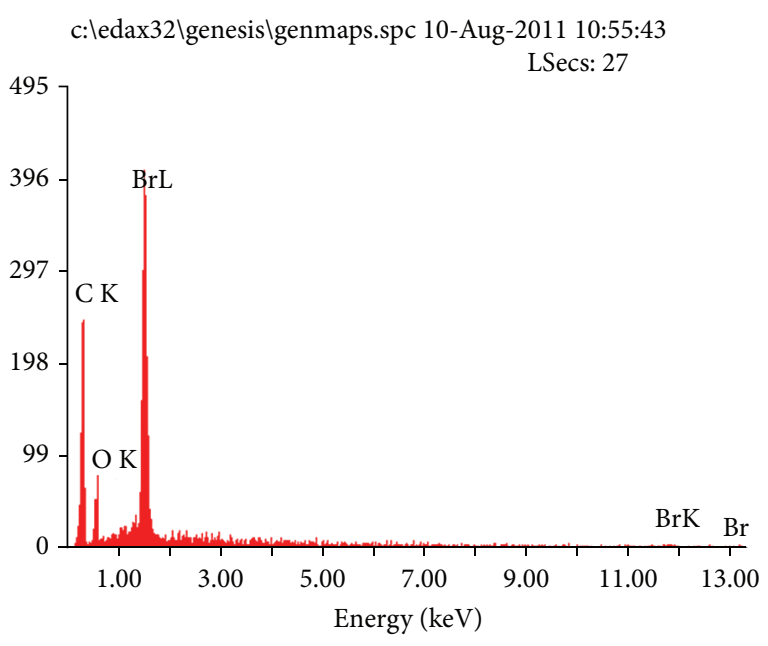

Figure 1: EDAX of $3 \mathrm{~h}$ Br-PEEK.

transferred in to the reaction flask and finally raised the temperature up to $180-200^{\circ} \mathrm{C}$. The concentration of catalyst was varied as $5,10,15$, and $20 \mathrm{~mol} \%$ and attributed as $5 \mathrm{~m}$, $10 \mathrm{~m}, 15 \mathrm{~m}$, and $20 \mathrm{~m}$. Application of nitrogen stream provides the inert medium and simultaneously drives off evolved vapors. A homogeneous, brownish solution was obtained. Above the $160^{\circ} \mathrm{C}, 2-4$ drops of triethylphosphite were added in the reaction flask. Further, the batch was kept under slow stirring at $180-200^{\circ} \mathrm{C}$ for $8-10 \mathrm{~h}$. The reaction mixture was turned black as the reaction proceeded. A solid polymer was obtained by precipitation of reaction mixture into methanol. Polymer content was decanted and subsequently suspended in water. For removal of catalyst residue, the water-suspended polymer was sonicated in Ultrasonicator (UTS-120, Unitech Ultrasonics) for $15 \mathrm{~min}$. Polymer was filtered and dried at $100^{\circ} \mathrm{C}$. Hydrolysis of phosphonated polymer (P-PEEK) was carried out by refluxing with concentrated $\mathrm{HCl}$ for $50 \mathrm{~h}$. After complete washing with distilled water and drying in vacuum oven, the white solid polymer was obtained.

The characterizations of polymers were done by the following equipment-elemental analysis by EDAX detector equipped in FEI Quanta 200FC SEM system, IR spectra by Thermo-Nicolet Nexus FT-IR spectrometer, ${ }^{1} \mathrm{H}$ NMR by Bruker AC500 MHz NMR spectrometer, and thermal analysis by EXSTAR TG/DTA 6300. Proton conductivity of P-PEEK film sample was determined by Impedance Gain Phase Analyzer (Solartron SL1260) in which Julabo S25 was equipped for temperature variation.

\section{Results and Discussion}

\subsection{Characterization of Brominated PEEK (Br-PEEK)}

3.1.1. Elemental Analysis of Br-PEEK by EDAX. The $\mathrm{wt} \% \mathrm{of} \mathrm{C}$, $\mathrm{O}$, and $\mathrm{Br}$ in mono- and dibrominated PEEK was calculated theoretically (Table 1) and also measured by EDAX system (Figure 1 and Table 2). EDAX system attached with SEM was unable to measure the hydrogen weight. Therefore, during theoretical calculation we have eliminated the hydrogen 


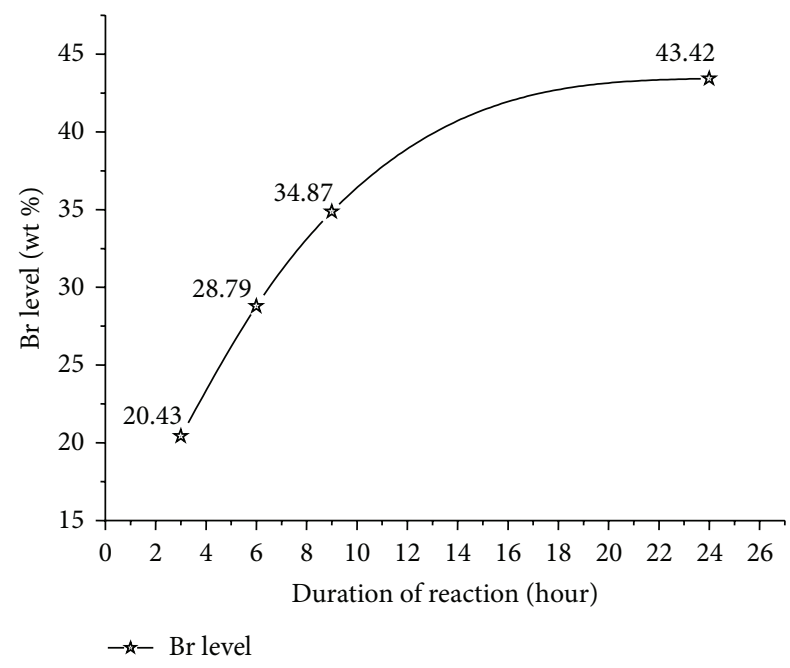

FIgURE 2: Bromine level in Br-PEEK polymer.

weight and assumed the total weight as $100 \%$. Br level increased with increasing the duration of reaction (Figure 2). The wt.\% of Br in sample $3 \mathrm{~h}$ was found equal to the calculated wt $\%$ of monobrominated PEEK, while in sample $9 \mathrm{~h}$ it was found to be close to the calculated wt.\% of dibrominated PEEK that is about $37 \%$ (Table 2). The wt $\%$ was correlated with degree of substitution (DS) by using $[12,13]$.

$$
\mathrm{DS}=\frac{m Y}{\left(100 W-W_{s} Y\right)},
$$

where $m$ is molar mass of repeat unit, $W$ is the formula weight of the substituent group, $W_{s}$ is the net increase in formula weight due to the introduction of substituent group per unit, and $Y$ is the wt.\% of substituent. The value of DS was found to be $0.89(3 \mathrm{~h}), 1.60(6 \mathrm{~h}), 1.85(9 \mathrm{~h})$, and $2.65(24 \mathrm{~h})$.

3.1.2. FTIR Analysis of Br-PEEK. FTIR spectrum of pure PEEK polymer was reported by the Nguyen and Ishida [14], Varsanyi [15], and Bellamy [16]. The typical absorption band reported in PEEK polymer was found almost same as BrPEEK (Figure 3). In general, the $\mathrm{C}-\mathrm{Br}$ stretching vibration in organic compound was reported in the range of 700$500 \mathrm{~cm}^{-1}$ while in [17] it was reported that aliphatic hydrocarbon showed the C-Br stretching in the range of $700-500 \mathrm{~cm}^{-1}$ whereas aromatic hydrocarbon showed the $\mathrm{C}-\mathrm{Br}$ stretching in the region of $1200-1000 \mathrm{~cm}^{-1}$ (strong multiple bands). A new doublet band was observed near $1066-1053 \mathrm{~cm}^{-1}$ in $\mathrm{Br}-$ PEEK which may be due to $\mathrm{C}-\mathrm{Br}$ stretching vibration. Since pure PEEK has many absorption bands in the region of 700$500 \mathrm{~cm}^{-1}$ therefore it is very difficult to assign the specific bands for $\mathrm{C}-\mathrm{Br}$ stretching in this region.

3.1.3. ${ }^{1} H$ NMR Spectra of Br-PEEK. Since pure PEEK is insoluble in organic solvents except in strong acids, therefore its ${ }^{1} \mathrm{H}-\mathrm{NMR}$ spectrum could not be recorded. The ${ }^{1} \mathrm{H}$ NMR of brominated sample is shown in Figure 4. Br-PEEK ( $3 \mathrm{~h}$ ) showed signal between the region 7.78-7.85 (m) ppm, 7.40

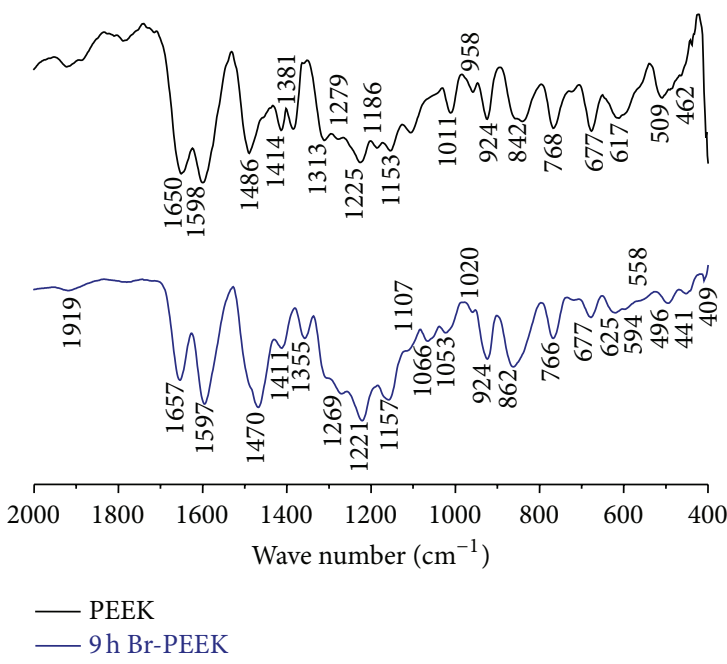

FIGURE 3: FTIR of PEEK and $9 \mathrm{~h}$ Br-PEEK.

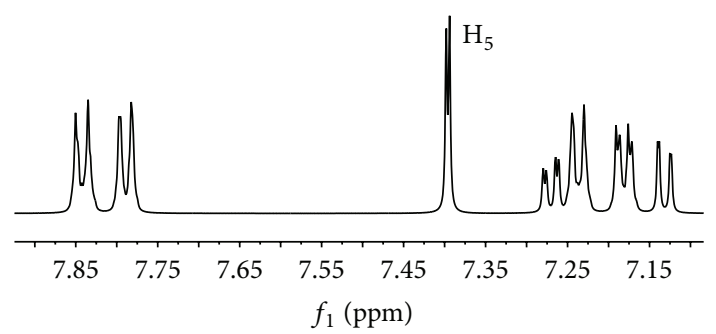

Figure 4: ${ }^{1} \mathrm{H}$ NMR of $3 \mathrm{~h}$ Br-PEEK.

(d) ppm, 7.26-7.28 (dd) ppm, 7.17-7.24 (m) ppm, and 7.12-7.14 (dd) ppm. These signals were observed in the aromatic region and associated with Ar-H. The signal 7.40 (d) ppm was found due to substitution of bromine group in the hydroquinone segment.

Further, a distinct signal at 8.00 (d) ppm and 7.62 (dd) ppm was obtained in $9 \mathrm{~h}$ and $24 \mathrm{~h}$ samples which may be associated with the neighbouring proton of substituted benzophenone segment of Br-PEEK. The substitution in benzophenone segment of PEEK polymer was also reported by the Conceição et al. [18]. The DS in Br-PEEK was also determined by measuring the ratio of intensity of the distinct signal with integrated intensity of the signals corresponding to all the other aromatic hydrogens [10]. The DS obtained by the NMR was found lower in comparison to the DS obtained by the elemental analysis (EDAX data) $(0.74(3 \mathrm{~h}), 1.23(6 \mathrm{~h})$, 1.65 (9h), $2.38(24 \mathrm{~h})$ ).

\subsection{Characterization of Phosphonated PEEK (P-PEEK)}

3.2.1. FTIR Spectra of P-PEEK. P-PEEK was characterized by the FTIR spectrometer. The main reported absorption bands are as follows. González et al. [19] assigned the $\mathrm{P}=\mathrm{O}$ stretching in the range of $1240-807 \mathrm{~cm}^{-1}$. Trotta et al. [20] assigned the $\mathrm{P}=\mathrm{O}$ stretching at $1240 \mathrm{~cm}^{-1}$. According to Stuart [21] the characteristic infrared bands in phosphonated aromatic compounds are as follows: (1) aromatic $\mathrm{P}=\mathrm{O}$ stretching in 
TABLE 3: Element \% in P-PEEK ester by EDAX.

\begin{tabular}{lccccc}
\hline \multirow{2}{*}{ Element } & Calculated wt\% & \multicolumn{4}{c}{ Measured wt\% } \\
& & $5 \mathrm{~m}$ & $10 \mathrm{~m}$ & $15 \mathrm{~m}$ & $20 \mathrm{~m}$ \\
\hline $\mathrm{C}$ & 68.49 & 65.94 & 67.34 & 70.41 & 72.01 \\
$\mathrm{O}$ & 23.82 & 13.69 & 15.06 & 18.46 & 19.93 \\
$\mathrm{P}$ & 7.69 & 1.73 & 2.98 & 4.15 & 6.02 \\
$\mathrm{Br}$ & - & 18.46 & 13.86 & 6.07 & 0.82 \\
$\mathrm{Ni}$ & - & 0.18 & 0.76 & 0.91 & 1.22 \\
\hline
\end{tabular}

between $1350-1300 \mathrm{~cm}^{-1}$, (2) aromatic P-C stretching in between $1450-1430 \mathrm{~cm}^{-1}$, and (3) phosphorus ester $\mathrm{P}-\mathrm{OH}$ stretching in the region $1040-930 \mathrm{~cm}^{-1}$. The spectrum of pristine PEEK shows many absorption bands in the above mentioned region such as asymmetric stretching of diphenyl ether groups in the region of $1227 \mathrm{~cm}^{-1}$ and $1190 \mathrm{~cm}^{-1}$. Therefore, a clear identification of addition of phosphonate ester group was somewhat difficult. From the comparison of spectra of P-PEEK ester and PEEK (Figure 5), we found the new absorption band at $1250-1233 \mathrm{~cm}^{-1}, 1470 \mathrm{~cm}^{-1}$, and doublet at $1036 \mathrm{~cm}^{-1}$ which might be due to the presence of $\mathrm{P}=\mathrm{O}$ stretching, $\mathrm{P}-\mathrm{C}$ stretching, and phosphorus ester $\mathrm{P}-$ $\mathrm{OH}$ stretching, respectively. All other characteristics band of PEEK such as presence of carbonyl group at $1651 \mathrm{~cm}^{-1}$ remained the same in P-PEEK derivatives.

3.2.2. Elemental Analysis by EDAX. The wt.\% of different elements in P-PEEK ester derivatives were determined by EDAX (Figure 6) and also calculated theoretically by ignoring the hydrogen atom as like in Br-PEEK. Table 3 represented the calculated and measured wt\% of different elements in monophosphonated P-PEEK ester. The wt $\%$ of phosphorous in different P-PEEK ester samples were found lower than the calculated wt\% of monophosphonated PEEK (7.69 wt\%). It was observed that P-PEEK samples have some bromine. The DS was calculated according to (1) whose values were $\sim 0.17$, $0.30,0.45$ and $0.71 \mathrm{in} \mathrm{P-PEEK}$ ester $5 \mathrm{~m}, 10 \mathrm{~m}, 15 \mathrm{~m}$ and $20 \mathrm{~m}$ respectively.

3.2.3. Solubility of P-PEEK Ester and P-PEEK Acid. The solubility of P-PEEK ester and P-PEEK acid were determined by visual inspection in various solvent at room temperature and also at high temperature $>150^{\circ} \mathrm{C}$. It was found that both are insoluble in almost all the organic solvents. NMP sparingly dissolved the P-PEEK acid and ester both only at high temperature. Further, addition of 2-3 drops of acid such as $\mathrm{HBr}$ or $\mathrm{H}_{2} \mathrm{SO}_{4}$ fairly dissolved the both form of polymer (Table 4).

3.2.4. NMR Characterization of P-PEEK. Solubility of PPEEK ester was not found in any normal available deuterated solvent. Therefore, characterization of P-PEEK in liquid stage was somewhat difficult. To resolve the problem of solubility, initially a concentrated solution of P-PEEK ester in NMP at higher temperature was prepared which was
TABLE 4: Solubility of P-PEEK acid and ester in various solvents.

\begin{tabular}{lcc}
\hline \multirow{2}{*}{ Solvent } & \multicolumn{2}{c}{ Phosphonated PEEK } \\
& Room temp. & Temp. $>150^{\circ} \mathrm{C}$ \\
\hline DMSO & $\mathrm{C}$ & $\mathrm{C}$ \\
DMAC & $\mathrm{C}$ & $\mathrm{C}$ \\
NMP & $\mathrm{C}$ & $\mathrm{B}$ \\
DMF & $\mathrm{C}$ & $\mathrm{B}$ \\
$\mathrm{DMSO}^{+}$ & $\mathrm{C}$ & $\mathrm{B}$ \\
$\mathrm{DMAC}^{+}$ & $\mathrm{C}$ & $\mathrm{B}$ \\
$\mathrm{NMP}^{+}$ & $\mathrm{C}$ & $\mathrm{A}$ \\
DMF $^{+}$ & $\mathrm{C}$ & $\mathrm{C}$ \\
$4-\mathrm{Chlorophenol}^{+}$ & $\mathrm{C}$ & $\mathrm{C}$ \\
$\mathrm{THF}^{+}$ & $\mathrm{C}$ & $\mathrm{C}$ \\
Cyclohexanone $^{+}$ & $\mathrm{C}$ & $\mathrm{C}$ \\
\hline
\end{tabular}

${ }^{+}$Solvent and 2-3 drops of acid $\mathrm{HBr} / \mathrm{H}_{2} \mathrm{SO}_{4}$, A: soluble, B: Sparingly soluble, C: not soluble.

further utilized in DMSO- $d_{6}$ to prepare a solution of P-PEEK ester-NMP/DMSO- $d_{6}$ in the ratio of $1 / 3$. The ${ }^{1} \mathrm{H}$ NMR spectra of NMP and P-PEEK ester-NMP in DMSO- $d_{6}$ were determined, respectively. NMP showed the signal at $3.4 \mathrm{ppm}$, $2.85 \mathrm{ppm}, 2.37 \mathrm{ppm}$, and $2.30 \mathrm{ppm}$. The signal near $2.5 \mathrm{ppm}$ was associated with DMSO- $d_{6}$. These entire signals were also found in P-PEEK ester-NMP sample. P-PEEK ester gave signal in both aromatic and also in aliphatic regions (Figure 7) due to presence of aromatic protons and protons of ethyl ester at $4.46 \mathrm{ppm}$ and $1.19 \mathrm{ppm}$. Aryl phosphonation effected a downfield shift of proton neighbouring to phosphonic ester group as well as a broadening and splitting of signals into a doublet of doublets [5]. The broadening, splitting of signal, and downfield shifting were also found in case of P-PEEK samples as the degree of phosphonation increases (Figure 7). The degree of phosphonation can be calculated from the signal ratio of the ethyl ester protons and the protons of aromatic region [4] which was observed $0.14,0.25,0.42$, and 0.68 in P-PEEK ester $5 \mathrm{~m}, 10 \mathrm{~m}, 15 \mathrm{~m}$, and $20 \mathrm{~m}$, respectively. Phosphonation in PEEK polymer was also confirmed by the solid state ${ }^{31} \mathrm{P}$ NMR spectrum of P-PEEK (Figure 8) which showed only a single signal at $12.52 \mathrm{ppm}$. Single peak was also reported by Bock et al. [5] in case of ${ }^{31} \mathrm{P}$ NMR spectra of PPSU acid.

3.2.5. Thermal Analysis of P-PEEK. P-PEEK ( $20 \mathrm{~m})$ showed $T_{g} 220^{\circ} \mathrm{C}$ and $T_{m} \sim 381^{\circ} \mathrm{C}$ which was about $44^{\circ} \mathrm{C}$ higher than the PEEK polymer. It shows that P-PEEK exhibited higher thermal stability than PEEK polymer $\left(T_{g} 152^{\circ} \mathrm{C}, T_{m} 337^{\circ} \mathrm{C}\right)$ (Figure 9). A significant wt. loss was found at $313^{\circ} \mathrm{C}$ which may be possible due to the conversion of phosphoric acid segment in to anhydride (Figure 10). P-PEEK also showed the higher residual mass, which may be possible due to presence of incombustible phosphorus oxides.

3.2.6. Proton Conductivity P-PEEK. Proton conductivity of P-PEEK was determined by casting the film on Indium-tin oxide (ITO) coated glass sheet using the solvent NMP. Coated 


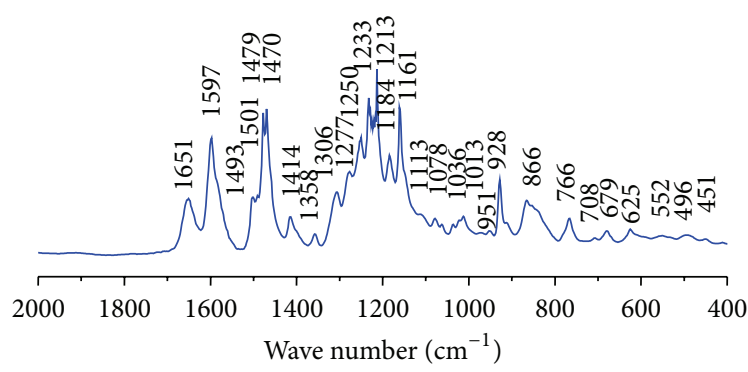

— P-PEEK

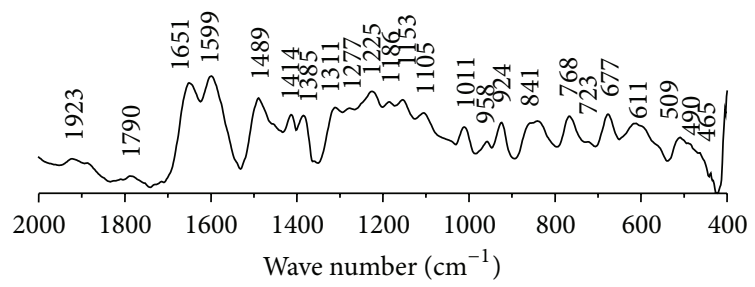

— PEEK

(a)

(b)

FIGURE 5: FTIR of P-PEEK ester (20 m).

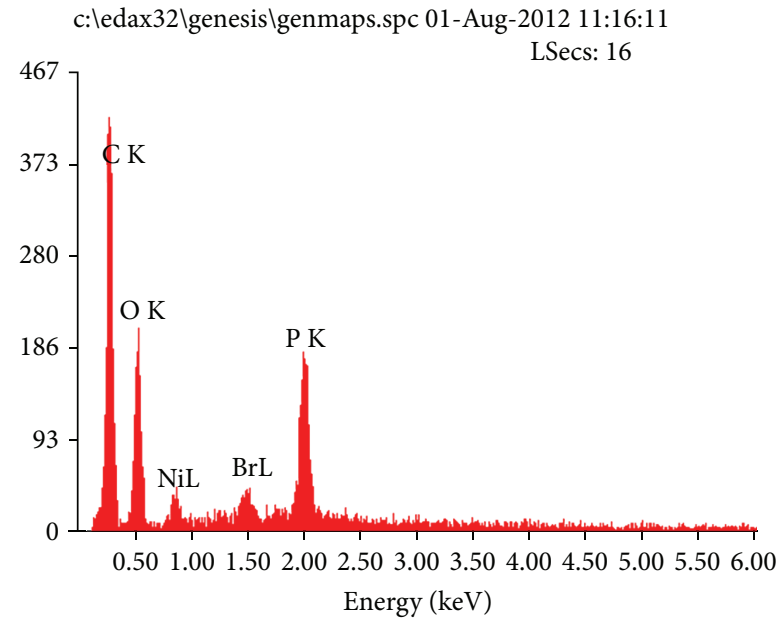

FIgURE 6: EDAX of P-PEEK ester (20 m).

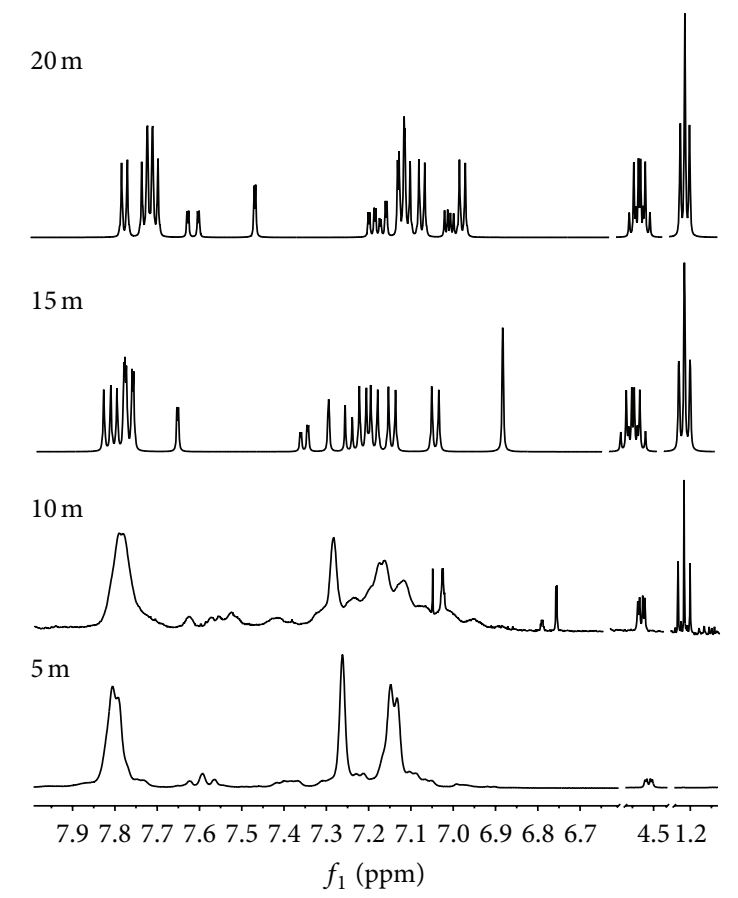

Figure 7: ${ }^{1} \mathrm{H}$ NMR of P-PEEK ester $5 \mathrm{~m}, 10 \mathrm{~m}, 15 \mathrm{~m}$, and $20 \mathrm{~m}$.
31P CPMAS@ $14 \mathrm{kHz}$

phosphonic acid containing

org. polymer

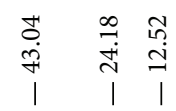

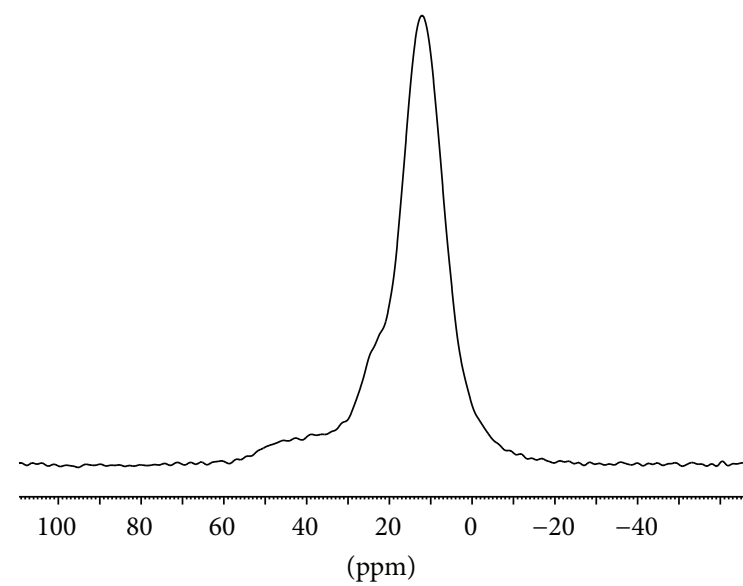

Figure 8: Solid state ${ }^{31} \mathrm{P}$ NMR of P-PEEK acid.

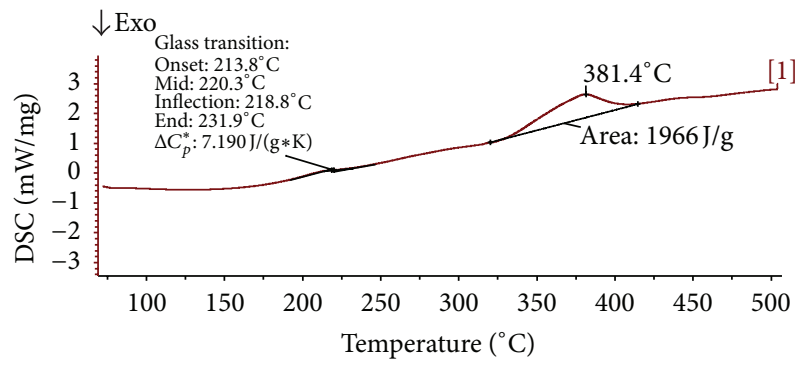

[1] P-PEEK (20 m).imp

- DSC

Figure 9: DSC of P-PEEK (20 m).

glass sheet was further dipped in water for $24 \mathrm{~h}$. The thickness of polymer film was determined by taking the difference in glass sheet thickness before and after the coating. The polymer coated sheet was sandwiched with ITO coated glass sheet, and impedance was measured by varying the frequency 


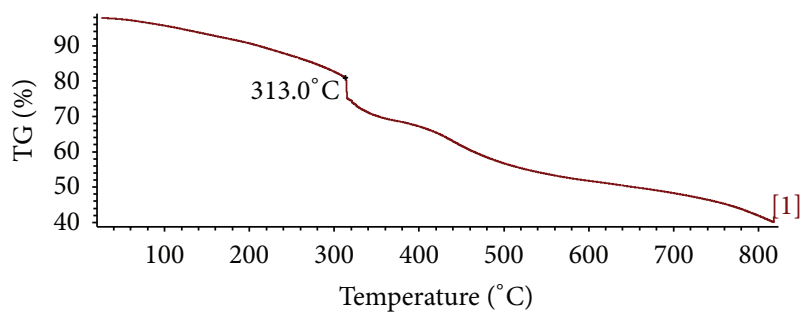

[1] P-PEEK (20 m).imp — TG

Figure 10: TGA of P-PEEK (20 m).

TABLE 5: Proton conductivity of polymer membranes.

\begin{tabular}{lccc}
\hline Membrane & \multicolumn{3}{c}{ Proton conductivity $\left(\mathrm{S} \mathrm{cm}^{-1}\right)$} \\
\hline \multirow{3}{*}{ Nafion } & $0.06-0.100$ & 0.19 & 0.210 \\
& $\left(25-30^{\circ} \mathrm{C}\right)$ & $\left(90^{\circ} \mathrm{C}\right)$ & $\left(120^{\circ} \mathrm{C}\right)$ \\
& {$[8]$} & {$[8]$} & {$[9]$} \\
\multirow{3}{*}{ SPEEK } & 0.008 & 0.076 & 0.033 \\
& $\left(25^{\circ} \mathrm{C}\right)$ & $\left(100^{\circ} \mathrm{C}\right)$ & $\left(120^{\circ} \mathrm{C}\right)$ \\
& $(\mathrm{DS} 0.80)$ & $(\mathrm{DS} 0.80)$ & $(\mathrm{DS} 0.83)$ \\
\multirow{2}{*}{ P-PEEK $(20 \mathrm{~m})$} & {$[10]$} & {$[10]$} & {$[11]$} \\
\hline
\end{tabular}

$100 \mathrm{~Hz}$ to $32 \mathrm{MHz}$, AC voltage $50-500 \mathrm{mV}$ in Impedance Gain Phase Analyzer (Solartron SL1260). Julabo S 25 was used for variation in temperature during the impedance measurement. Proton conductivity was calculated by the following equation $\sigma=L / R A$, where $L, R$, and $A$ are the distance between the two electrodes, membrane resistance, and cross-sectional area of the membrane, respectively [2224]. The value of $R$ was determined by plotting the graph between the impedance of real and imaginary plot (Figure 12). The point of resistance was that where the imaginary part was found to be zero. Conductivity of the P-PEEK samples increases with temperature and degree of phosphonation. The proton conductivity P-PEEK- $20 \mathrm{~m}$ was found $0.0069 \mathrm{~S} \mathrm{~cm}^{-1}$ at $25^{\circ} \mathrm{C}, 0.055$ at $65^{\circ} \mathrm{C}, 0.083 \mathrm{~S} \mathrm{~cm}^{-1}$ at $90^{\circ} \mathrm{C}$, and $0.114 \mathrm{~cm}^{-1}$ at $120^{\circ} \mathrm{C}$ (Figure 11 and Table 5). The Nafion membrane has been reported best ionic conductor at low temperature and high humidity $[8,25]$. S-PEEK membrane showed comparable proton conductivity with Nafion at high degree of sulfonation and humidity. Both Nafion and S-PEEK membrane exhibited loss of conductivity and physical failure at temperature $>100^{\circ} \mathrm{C}$. The loss of conductivity was found greater in SPEEK. Although conductivity of P-PEEK was found to be slightly lower than Nafion at $>100^{\circ} \mathrm{C}$ but its thermal stability was found higher, and it is expected that P-PEEK will show better durability with acceptable proton conductivity in comparison to both Nafion and S-PEEK.

\section{Conclusions}

Commercial PEEK polymer can be brominated with only a small excess of bromine in $\mathrm{H}_{2} \mathrm{SO}_{4}$. However, no catalyst was used during the reaction. FTIR, EDAX, and ${ }^{1} \mathrm{H}-\mathrm{NMR}$

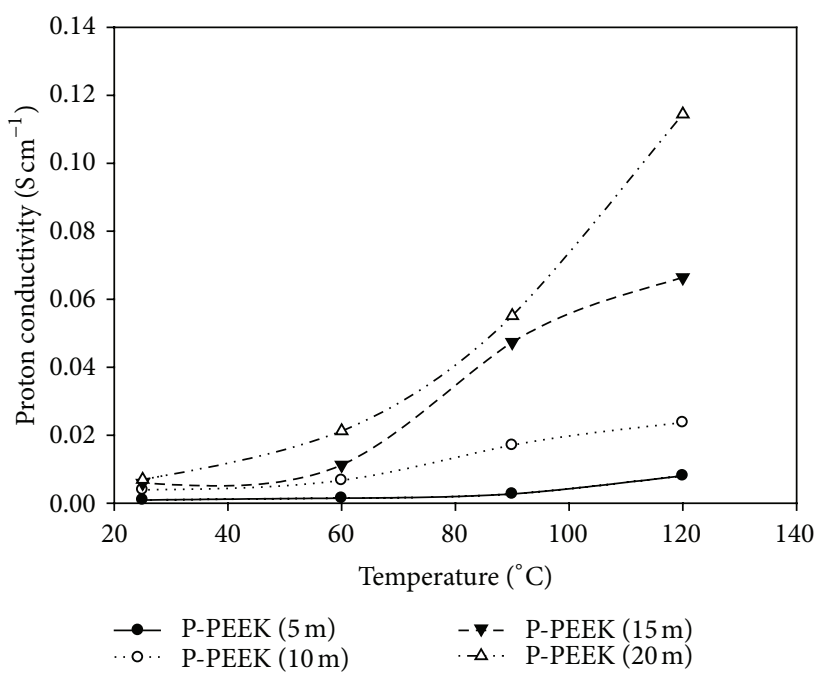

FIGURe 11: Proton conductivity of P-PEEK samples with temperature.

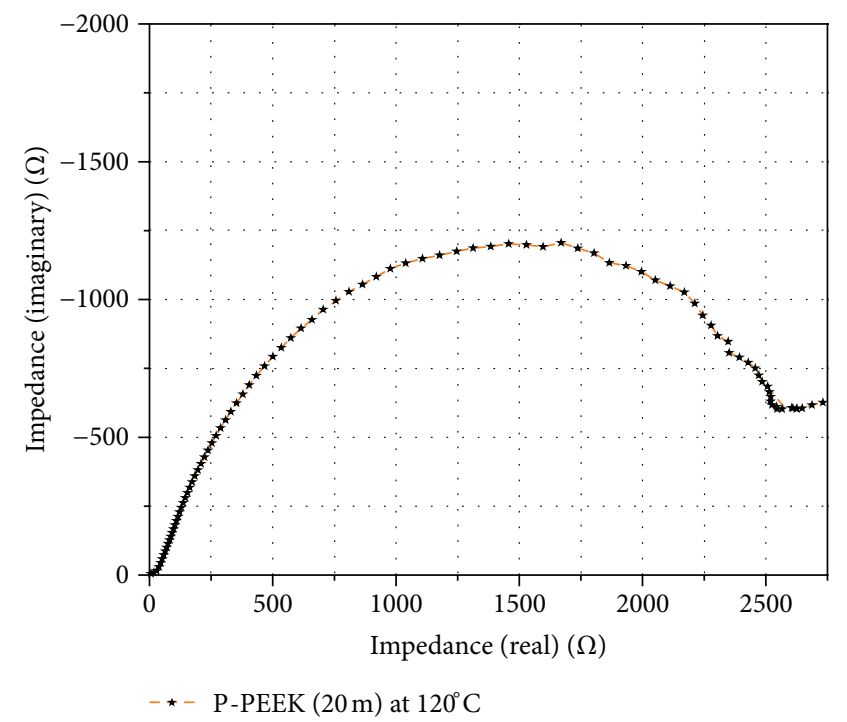

Figure 12: Nyquist plot of P-PEEK (20 m).

indicated that PEEK can be brominated readily. Further, conversion of Br-PEEK in to P-PEEK was carried out in presence of nickel-based catalyst. P-PEEK was characterized by various techniques, and it was found that P-PEEK showed high thermal stability in relation with PEEK polymer and solubility in NMP at higher temperature. The proton conductivity of P-PEEK was compared with Nafion at $>100^{\circ} \mathrm{C}$ which showed slightly low value but thermal stability of P-PEEK was found good. Thus, it is expected that P-PEEK will show better durability with acceptable proton conductivity in comparison to both Nafion and S-PEEK at high temperature.

\section{Acknowledgments}

One of the authors is thankful for financial support from the Ministry of Human Resource Development (MHRD), India, 
and also for NCL Pune, India, for carrying out solid state NMR.

\section{References}

[1] J. E. Mark, Polymer Data Handbook, Oxford University Press, 1999.

[2] D. Shukla, Y. S. Negi, J. S. Uppadhyaya, and V. Kumar, "Synthesis and modification of poly (ether ether ketone) and their properties: a review," Polymer Reviews, vol. 52, no. 2, pp. 189-228, 2012.

[3] S. D. Alexandratos, M. A. Strand, D. R. Quillen, and A. J. Walder, "Synthesis and characterization of bifunctional phosphinic acid resins," Macromolecules, vol. 18, no. 5, pp. 829-835, 1985.

[4] K. Jakoby, K. V. Peinemann, and S. P. Nunes, "Palladiumcatalyzed phosphonation of polyphenylsulfone," Macromolecular Chemistry and Physics, vol. 204, no. 1, pp. 61-67, 2003.

[5] T. Bock, R. Mülhaupt, and H. Möhwald, "Halogen-free polyarylphosphonates and polyelectrolyte membranes for PEMFC by Nickel-Catalyzed phosphonylation with silylated phosphates," Macromolecular Rapid Communications, vol. 27, no. 24, pp. 2065-2071, 2006.

[6] B. Lafitte and P. Jannasch, "Phosphonation of polysulfones via lithiation and reaction with chlorophosphonic acid esters," Journal of Polymer Science A, vol. 43, no. 2, pp. 273-286, 2005.

[7] T. M. Balthazor and R. C. Grabiak, "Nickel-catalyzed Arbuzov reaction: mechanistic observations," Journal of Organic Chemistry, vol. 45, no. 26, pp. 5425-5426, 1980.

[8] S. Slade, S. A. Campbell, T. R. Ralph, and F. C. Walsh, "Ionic conductivity of an extruded Nafion $1100 \mathrm{EW}$ series of membranes," Journal of the Electrochemical Society, vol. 149, no. 12, pp. A1556-A1564, 2002.

[9] N. Miyake, J. S. Wainright, and R. F. Savinell, "Evaluation of a sol-gel derived nafion/silica hybrid membrane for proton electrolyte membrane fuel cell applications: I. Proton conductivity and water content," Journal of the Electrochemical Society, vol. 148, no. 8, pp. A898-A904, 2001.

[10] S. M. J. Zaidi, S. D. Mikhailenko, G. P. Robertson, M. D. Guiver, and S. Kaliaguine, "Proton conducting composite membranes from polyether ether ketone and heteropolyacids for fuel cell applications," Journal of Membrane Science, vol. 173, no. 1, pp. 17-34, 2000.

[11] B. Lakshmanan, W. Huang, D. Olmeijer, and J. W. Weidner, "Poly(ether ether ketone) membranes for elevated temperature PEMFCs," Electrochemical and Solid-State Letters, vol. 6, no. 12, pp. A282-A285, 2003.

[12] A. Philippides, P. M. Budd, C. Price, and A. V. Cuncliffe, "The nitration of polystyrene," Polymer, vol. 34, no. 16, pp. 3509-3513, 1993.

[13] "Degree of Substitution," in Encyclopedia of Polymer Science and Technology, John Wiley \& Sons, 2002.

[14] H. X. Nguyen and H. Ishida, "Molecular analysis of the crystallization behavior of poly(aryl-ether-ether-ketone)," Journal of Polymer Science B, vol. 24, no. 5, pp. 1079-1091, 1986.

[15] G. Varsanyi, Assignments for Vibrational Spectra of Seven Hundred Benzene Derivatives, Adam Hilger, London, UK, 1974.

[16] J. L. Bellamy, The Infrared Spectra of Complex Molecule, Chapman and Hall, London, UK, 3rd edition, 1975.

[17] Sadtler Handbook of Infrared Spectra, Bio-Rad Laboratories, Informatics Division.

[18] T. F. Conceição, J. R. Bertolino, G. M. O. Barra, S. L. Mireski, A. C. Joussef, and A. T. N. Pires, "Preparation and characterization of poly (ether ether ketone) derivatives," Journal of the Brazilian Chemical Society, vol. 19, no. 1, pp. 111-116, 2008.

[19] L. González, O. Mó, M. Yáñez, and J. Elguero, "Very strong hydrogen bonds in neutral molecules: the phosphinic acid dimers," Journal of Chemical Physics, vol. 109, no. 7, pp. 26852693, 1998.

[20] F. Trotta, S. C. Mio, K. Martina, E. Drioli, and P. Finocchiaro, "New poly ether ether ketones containing phosphorus for membrane preparation," Asia-Pacific Journal of Chemical Engineering, vol. 5, no. 1, pp. 249-255, 2010.

[21] B. H. Stuart, "Organic molecules," in Infrared Spectroscopy, Fundamentals and Applications, pp. 71-93, John Wiley \& Sons, 2005.

[22] C. Zhao, H. Lin, K. Shao et al., "Block sulfonated poly (ether ether ketone)s (SPEEK) ionomers with high ion-exchange capacities for proton exchange membranes," Journal of Power Sources, vol. 162, no. 2, pp. 1003-1009, 2006.

[23] P. Xing, G. P. Robertson, M. D. Guiver, S. D. Mikhailenko, $\mathrm{K}$. Wang, and S. Kaliaguine, "Synthesis and characterization of sulfonated poly (ether ether ketone) for proton exchange membranes," Journal of Membrane Science, vol. 229, no. 1-2, pp. 95-106, 2004.

[24] N. Zhang, G. Zhang, D. Xu et al., "Cross-linked membranes based on sulfonated poly (ether ether ketone) (SPEEK)/Nafion for direct methanol fuel cells (DMFCs)," International Journal of Hydrogen Energy, vol. 36, no. 17, pp. 11025-11033, 2011.

[25] G. Alberti, M. Casciola, L. Massinelli, and B. Bauer, "Polymeric proton conducting membranes for medium temperature fuel cells $\left(110-160^{\circ} \mathrm{C}\right)$, , Journal of Membrane Science, vol. 185, no. 1, pp. 73-81, 2001. 

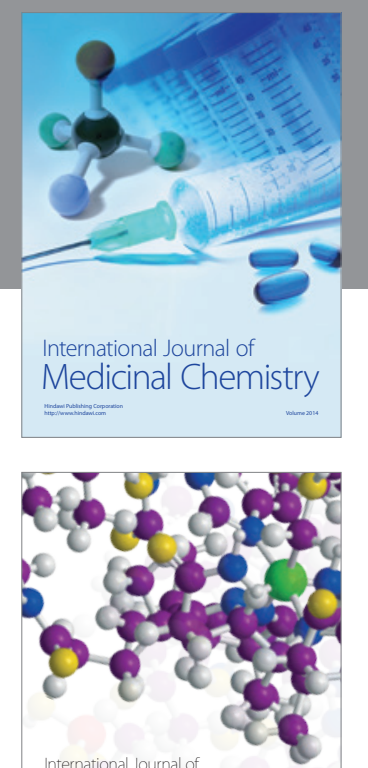

\section{Carbohydrate} Chemistry

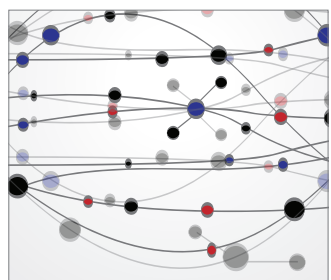

The Scientific World Journal
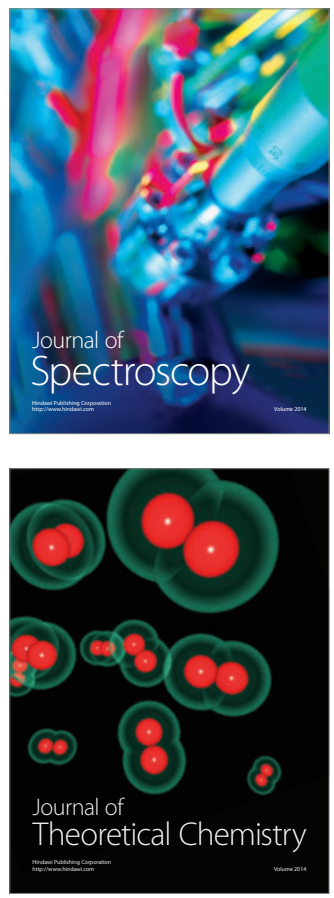
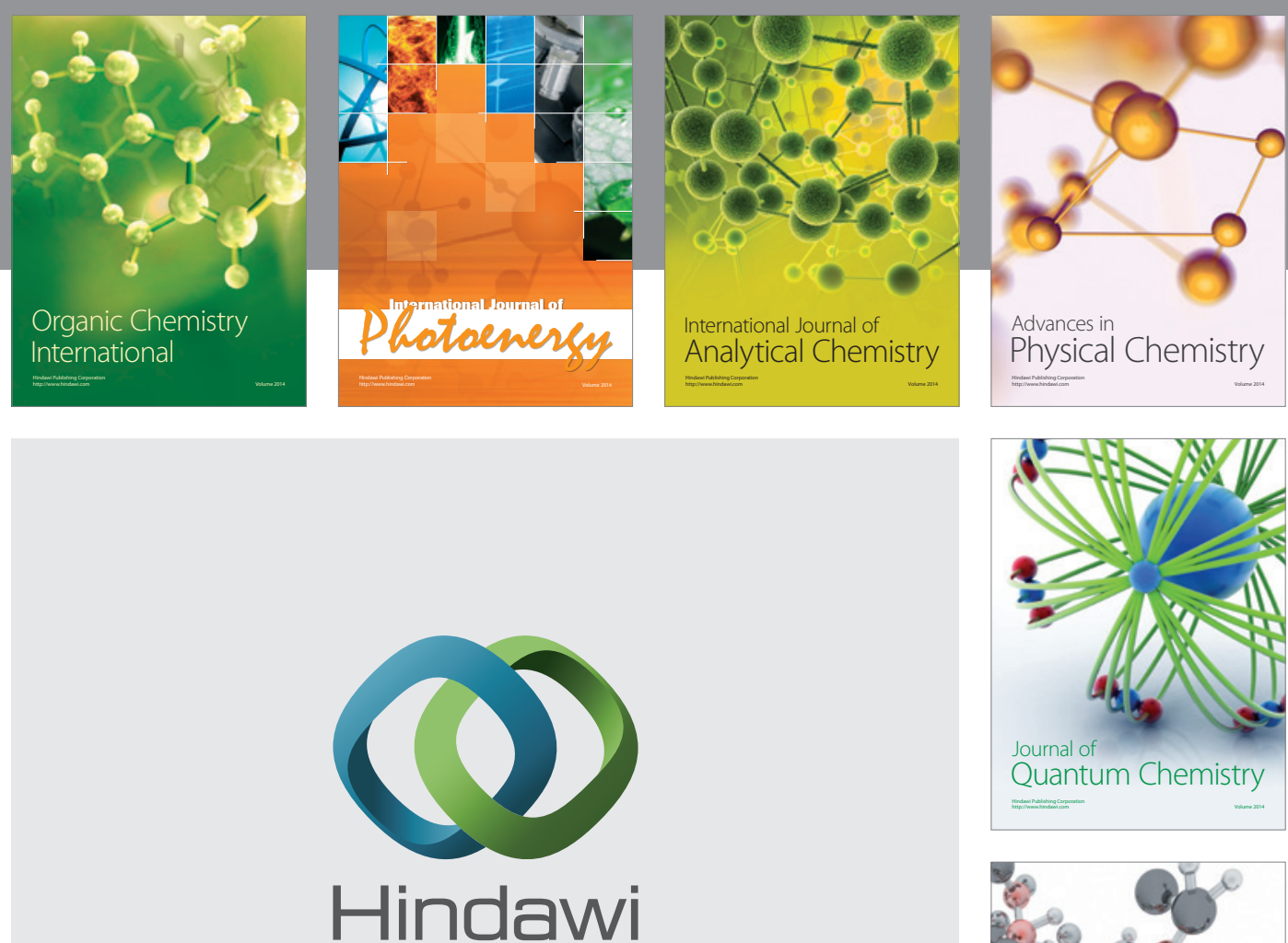

Submit your manuscripts at

http://www.hindawi.com

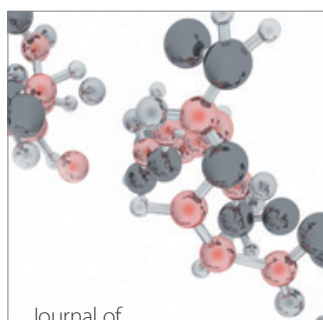

Analytical Methods

in Chemistry

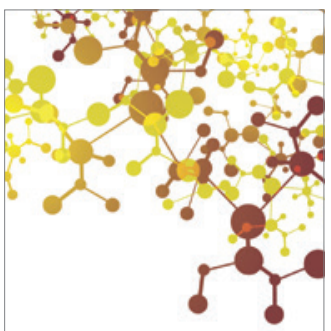

Journal of

Applied Chemistry

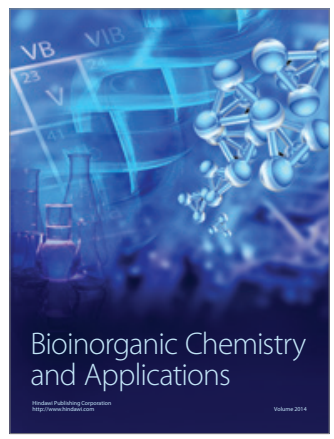

Inorganic Chemistry
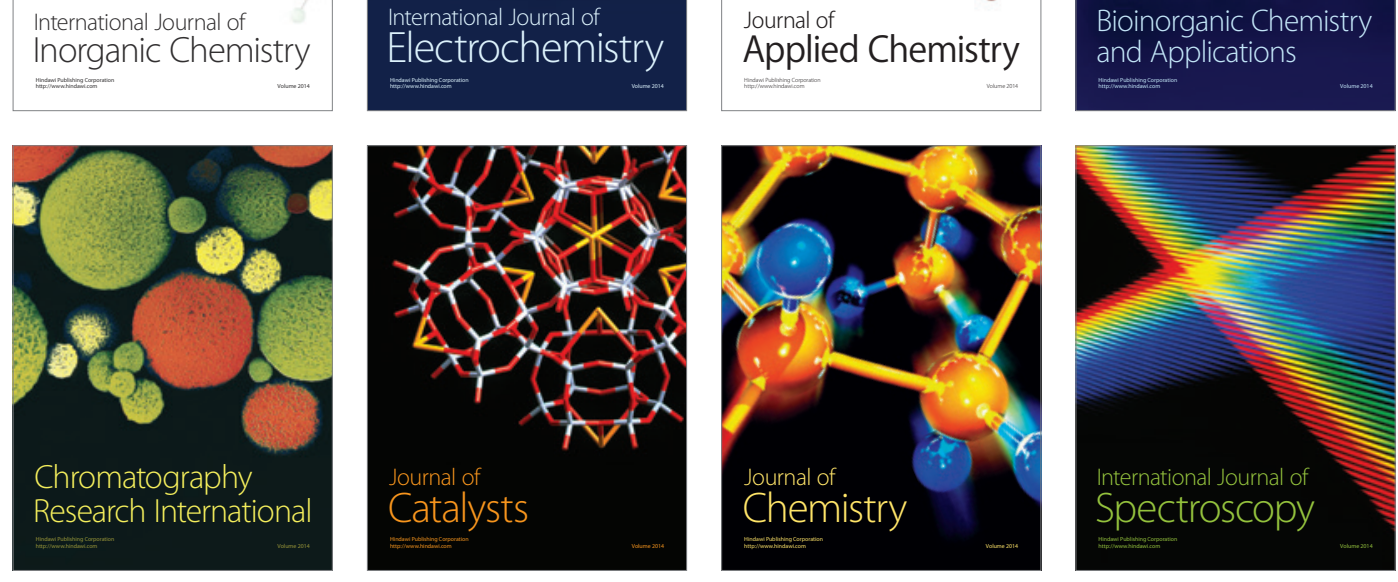